\title{
Mechanism of Management of Retail Networks Services
}

\author{
Valeeva J.S. \\ University of Management TISBI, \\ Kazan State Energetic University \\ Kazan, Russia \\ Valis2000@mail.ru \\ Naida A.M. \\ University of Management TISBI \\ Kazan, Russia \\ anajda1979@gmail.com
}

\author{
Potapova N.K. \\ University of Management TISBI \\ Kazan, Russia \\ nmetlach@yandex.ru \\ Elesin E.Yu. \\ University of Management TISBI \\ Kazan, Russia \\ yyelesin@yandex.ru
}

\begin{abstract}
The main purpose of this research is consideration of the theoretical and methodological approaches to formation of the mechanism of management development of services of retail chains on the basis of consumer value. The effectiveness of trade services is considered from positions of value-oriented development which allows to provide the greatest benefits to consumers in the most retail chains and to participants of creation of consumer value of service. The mechanism of value-oriented development of services, consisting of three models at the meso level and micro level is presented. There are two interfaces of interaction - with consumers and with producers. Establishment of long-term interaction with participants of a chain, ensuring customer focus of consumers, creation of conditions for appeal of interaction with partners of retail chains will belong to the main objectives of the mechanism. The basic principles of development of services are presented by such indicators as orientation to the consumer, social responsibility of business, obtaining values from participation, customer focus, to part communication range, orientation to innovations the strategy of development of services KK, including the strategy of the advancing development in correlation with the basic and expected consumer values, conservative development as a factor of receiving extra time of consumer value and providing socially economic indicators of development trade services, catching up development as the potential level of receiving service by consumers is developed.
\end{abstract}

Keywords-client-oriented approach; value-oriented development; services; retail services.

\section{INTRODUCTION}

In modern conditions for trade growth of requirements to the range, quality of service, to additional services and need of ensuring competitiveness on commodity market and services is significant.

In the system of national economic complex of Russia, the main link is retail trade as it can be attributed to elements forming the quality system of population`s quality of life.
In the industry, there are active processes of merger and absorption, huge malls and megamalls owning modern technologies of the organization of business processes are under construction, many networks actively develop the system of franchising, there is an outsourcing process allocations of support functions from the main process in independent organizational structure.

As an important sphere of social development, for retail trade enterprises topical issue is content of the functions which are really carried out by retail trade and directly acting in type of service which are provided to the population and are subdivided into trade and technological functions.

Obviously, that the volume and nomenclature of functions performed by the retail trading enterprise depend on type and size, economic empowerment, technical equipment, location and other factors.

Yudaev A.V. [6] defines structure and discloses the content of functions of the enterprises of retail trade: realization of goods to an ultimate consumer: sale of goods, implementation of monetary operations(transactions), formation of the commodity and price policy, services to the population;

consumption organization: service in the process of selling goods, service in the process of consumption, promotion of goods and services;

consulting services: organization of information support of trade process, research of market conjecture, research of beneficial business linkages, automation of ordering process and storage, payment by buyers of bills on the system of electronic payments.

Each of the allocated functions serves the uniform purpose - a population requirements satisfaction in the goods and services provided with financial resources.

From the saturation of the consumer market goods, timeliness of their realization possibilities of development of production, degree of a requirements satisfaction and quality 
of life of the population and, eventually, efficiency of national economy depend.

Let us agree with Yudaev A.V. [6] that the problem of efficiency of retail trade has to be considered not as a position of production or services industry, but as an integral part of a common problem of efficiency of the national economy which providing a gross domestic product growth and a national income of society.

This study combines the research of foreign scientists on the analysis of digitalization of American and European retail networks and the implementation of innovations in the activities of Russian network organizations (Porter [1], Kozlova et al. [2], Shangina [3], Dolinina et al. [4], Sharafutdinova and Valeeva [5])

But, according to our opinion, supplementing this position, there is a question of the practical importance of forecasting of development of retail trade enterprises in the conditions of globalization and competition.

\section{LITERATURE REVIEW}

In modern conditions for trade growth of requirements to the range, quality of service, to additional services and need of ensuring competitiveness on commodity market and services is significant.

Issues of development of retail trade, formats of retail trade of services enterprises, including retail chains are reflected in detail in works such foreign authors as D.Gilbert, T.Kent, O.Omar and also such domestic (russian) scholars as V.Egorov, V.Radayeva [7], Ya.Sayamova, L.Hasisa.

Works of foreign authors I. Ansoff, G. Mintsberg, M. Porter, A. Strickland, A. Thompson and such domestic(ruccian) scholars as O. Vikhansky, A. Gorina, I. Gurkov, Ajupov A. [8] and etc. are devoted to the theoretical and methodological problems of model of enterprise strategy [9].

Essential need of effective work of the enterprises of service sector(industry), including the enterprises of retail trade, retail chains, through(thanks) to correctly chosen strategy, process of its realization caused the choice of a thesis, defined statement of the purpose, tasks and structure.

\section{RESEARCH METHODOLOGY}

Methodology of the development mechanism of services of retail chain stores is presented by expansion of category of ef ectiveness of services as the indicator of value-oriented development of services, allocation of tasks, principles, methods of management and formation of strategies of development of services of retail chains. According to our opinion, from a position of value-oriented development, it is necessary to understand ability of retail chains to form the resource potential providing to consumers' higher level of benefits of trade service the consumer value, and trade network social and economic advantages in comparison with other economic entities of this market values of network as the effectiveness of trade services.
Proceeding from essence of the offered determination of social and economic effectiveness of trade services from a position of value-oriented development, the author considers it in the following aspects:

1)the efficiency is considered rather concrete commodity and territorial market, has dynamic character and characterizes a condition of the subject on a certain interval of time;

2)In assessing the effectiveness there is an interaction of three main elements:

directly studied subject retail chains;

the consumer main appraiser of trade retailing service;

competitors concerning which comparison of the subject is made;

3)ability of ensuring social effectiveness, providing best trade retailing service to buyers and satisfaction of consumer expectations;

4)providing maximal economic benefit to the enterprise;

5)the effectiveness of retail chains is formed by the created value.

6)The result of economic effectiveness is economic effect which impact on growth in profits, cost savings, improvement of quality and etc.

The result of social effectiveness is social effect, including further training (skills development) of employees, improvement of foundation for the adopted decisions, formations of organizational culture, job satisfaction, earning of public trust, strengthening of social responsibility of the organization, environmental impact.

7)There is strong correlation between economic and social effectiveness very because it is often at improvement of an economic situation also the social satisfaction and conversely, at increase in social satisfaction the economic efficiency improves. Increase in profitability of the enterprise leads to increase in the salary (implementation of material stimulation) and, as a result, to satisfaction of employees. Increase in social satisfaction in turn promotes increase in productivity and improvement of quality and, as a result, increases profitability and etc. But it should be noted that events of social orientation can yield results only in the longterm future therefore similar actions should be compared with strategic and tactical plans in addition.

\section{RESULTS}

The involvement of participants into process of creation of consumer value (use values) of trade services demands development of the developed system of indicators allowing to operate the effectiveness of trade services at separate stages.

Considering the aforesaid for chains the system of indicators of assessment of social and economic efficiency from a position of value-oriented development of trade services will turn on the following blocks. 
At the first stage of RTS receives resources from the regional power - building land, personnel which gets an education in the region.

Therefore, it is necessary to allocate meso level in terms of investment appeal of retail chains for such participants of a chain as owners, investors, participants of the stock market.

Modern effective development of retail chains is inseparably linked with their transformation from industrial to the social organizations focused on clients, but not on the solution of intra-corporate trade and technological tasks.The concept of the enterprise for formation of trade services has to be implemented as specific social organization which social and economic efficiency of activity in many respects is defined by new ethics of business within its customer focus and social responsibility, the standard of work, ways of formation and development of personnel capacity of retail chain stores. Methodological justification of development of services of retail chains on the basis of the theory of a chain of creation of consumer value, network trade. The mission characterizes basic provisions of trade service, the purpose of development of services for participants of a chain and consists in creation of the socially responsible business aimed at the development of the territory and ensuring food security of the territory and also a population requirements satisfaction. The main participants of the mechanism are: goverment, society, producers, retail chains, providers of services, consumers

Our approach correlates with approach of professor Fedyunin in need of development of the theory of the industry analysis within an exchange of resources of participants of retail chains.

Therefore, at the basis we use meso level in which the analysis of investment appeal of service for investors and for other participants of a chain.

Carrying out social and economic efficiency, existence of synergetic effect within interaction of small and large enterprises in holding is important situation which we use and we treat that use values (consumer value) is formed by the accruing result from an agricultural producer to the consumer, participants of a chain, but not holding act as objects of a research.

This interaction is assumed available by Synergy B and also effective use in total resources.

The effectiveness of services for the investor - to receive return from invested funds, appeal of activity on this territory for development trade services.

Appeal to participants in a chain of creation of consumer value: government institutions and society, producers, including agricultural producers, mediators.

At the second level - micro level for participants: the most retail chains and consumers. For RTS optimization of all resources of expenses and results (through the quality management, management of process of creation of value through financial, personnel, commercial, trade management).
It is important to mark out customer focus of personnel and consumers from a position of increment of consumer value.

The customer-oriented personnel have to be focused on optimization of relations in a chain, the accruing result influencing increment of consumer value.

Consumers - the consumer who received services and the region which received return from interaction with RTS assignments of the loudspeaker, salary and quantity of employment.

The above-designated specification of the organizational and economic development mechanism of services of retail chains allowed to create the following elements.

The main objective of the mechanism is a creation of consumer value, increase in social and economic overall performance of the organization of trade.

The customer focus of consumers, appeal of participation in a chain to creation of consumer value to economic subjects or participants will belong to the main objectives of the considered mechanism.

The applied methods - the monetary, non-monetary and integrated methods, a method of the analysis, system approach, unity of the qualitative and quantitative analysis, special methods of a research: economical and statistical, expert.

To the main objectives will treat: - establishment of longterm interaction with participants of a chain of creation of consumer value of service of retail chains, - realization of expectations or estimated values for the participant of a chain and also obtaining benefit consumer interaction with the specific participant and retail chains, - creation of conditions for appeal of interaction of participants of a chain with retail retail chain stores and also joint creation of consumer value of trade service, - ensuring customer focus of consumers, appeal of participation in a chain to creation of consumer value to economic subjects or participants, - realization of value-oriented management will allow to provide the effectiveness of services and steady positions of retail chains.

Instruments of realization of the mechanism implementation of innovations, implementation of a quality management system, customer focus, state regulation of trade activity of the territorial subject of the Russian Federation, an intensification of use of resources, costs reduction; organization of increase in professional level of employees, acceptance and organization of implementation of plans and programs of complex social and economic development and schemes of territorial planning, observance of the standard of service.

Participants - government institutions and society, producers and processors, retail chains, intermediaries and consumers.

The basic principles of development of services are defined. 
The principle of orientation to the consumer is based that all operations in-retail chains, the organization of business processes, communications with participants in chains are directed to satisfaction of needs and inquiries of consumers.

The principle of social responsibility of business consists in implementation of social projects for society, creation of favorable social conditions for work to personnel, providing social benefits and requirements to consumers within providing trade service.

The principle of obtaining value from participation in a chain is implemented by each participant of a chain, otherwise his participation in a chain of creation of consumer value is inappropriate.

The principle of partnership in creation of consumer value is caused by the fact that each participant the accruing result creates consumer value and expands it under inquiries of consumers.

The principle of ensuring customer focus of personnel purposefully has to be implemented in activity of all economic subjects or participants of a chain as it is very important to provide performance of the unified quality standards of management and quality of goods and services, inquiries of customer focus of consumers.

The principle of realization of quality management is the principle which predetermines need to optimize all business processes in economic subjects or participants and also external business processes or types of activity between participants of a chain with the minimum expenses and increment of consumer value.

The principle of development of communication range by means of inclusion in structure of a chain of creation of consumer value of horizontal and vertical communications of the personified interactions which will allow to expand quantitative and qualitative opportunities of these interactions.

The principle of delocalization interaction by means of inclusion in the list of participants of a chain of new contractors without geographical restrictions.

The principle of transformation of the consumer in the participant of a chain of creation of value by means of customer focus and continuous monitoring and feedback with it.

The principle of expansion of participants of a chain due to involvement of stakeholders in process of formation of trade service by means of informal contracts.

The principle of strengthening of spatial development of network that finds expression in dependence of its configuration and arrangement of knots on points of concentration of resources.

The principle of adaptability to factors of the turbulent external environment and dynamism at the expense of high degree of the involvement of shopping facilities of network into the system of communication interactions with the changing configuration, existence of an effective system of feedback and coordination of activity of network with participation of all its participants.

The principle of orientation to open innovations that is caused by multidimensionality of organizational interactions and overcoming borders of private strategic processes of certain owners of the business processes focused on future consumer and providing formation of a uniform stream of value and distribution of innovations and also cooperation and integration of innovative competences of knots of network educations.

The principle of transformation of a configuration of life cycle of the organizations which are a part of a chain regarding reduction of a time interval of its formation that is caused by merging of the separate making organizational structures of customers and suppliers within development of new products, formation of the network innovative relations with the consumer of trade services.

The principle of development of network forms of selfregulation and self-organization on the basis of horizontal partnership with use of instruments of network management.

Strategies of development of service on the basis of increment of consumer value, management are determined by stages to types of activity of a chain or optimization of business processes ("E Business process - set of different types of activity within which "on an entrance" it is used one or more types of resources and as a result of this activity "at the exit" is created the product which is of value for the consumer"):

- the advancing development - the basic and expected level of consumer value of service and low level of socioeconomic indexes of valuable development of service (1-2 levels),

- conservative development the complemented level of consumer value of service and high level of socio-economic indexes of valuable development of service (the 4th level).

- the catching-up development - the potential level of consumer value of service and the average level of socioeconomic indexes of valuable development

\section{CONCLUSION}

Management of customer focus as a subsystem of management of retail chain stores is an important component. It considers micro level factors to which the economic environment, legal institutes, social development, a geographical location belong. Meso factors between level factors of direct impact on retail chain stores, including consumers, suppliers, competitors labor market and banking services belongs directly. All of them influence the level of

customer focus of retail and form cumulative consumer preferences. Trade plays a special role in the sector customer focus of personnel as important mobile to react to additional and new inquiries of consumers, constantly to have feedback with them, the personnel of valleys to be interested in joint value creation, are motivated and involved within all administrative processes of retail chain stores. 


\section{References}

[1] Porter, M.E.: Competitive Advantage: Creating and Sustaining Superior Performance. Free Press, New York. 1985

[2] Kozlova, O.A., Sukhostav, E.V., Anashkina, N.A., Tkachenko, O.N., Shatskaya, E.: Consumer model transformation in the digital economy era. In: Popkova, E., Ostrovskaya, V. (eds.) Perspectives on the Use of New Information and Communication Technology (ICT) in the Modern Economy. ISC 2017. Advances in Intelligent Systems and Computing. 2019, vol. 726, pp. 279-287. Springer, Cham. DOI: https://doi.org/10.1007/978-3-319-90835-9_33

[3] Shangina, E.I.: The triad of vitruvius in the modern world. In: Cocchiarella, L. (ed.) ICGG 2018 - Proceedings of the 18th International Conference on Geometry and Graphics. ICGG 2018. Advances in Intelligent Systems and Computing. 2019, vol. 809, pp. 2095-2107. Springer, Cham. https://doi.org/10.1007/978-3-31995588-9_187

[4] Dolinina, O.N., Kushnikov, V.A., Pechenkin, V.V., Rezchikov, A.F.: The way of quality management of the decision making software systems development. In: Silhavy, R. (ed.) Software Engineering and Algorithms in Intelligent Systems. CSOC2018 2018. Advances in Intelligent Systems and Computing. 2019, vol. 763, pp. 90-98). Springer, Cham. https:// doi.org/10.1007/978-3-319-91186-1_11

[5] Sharafutdinova, N., Valeeva, J.: Quality management system as a tool for intensive development of trade organizations. Mediterr. J. Soc. Sci. 2015, 6(N1S3), 498-502. https:// doi.org/10.5901/mjss.2015.v6n1s3p498

[6] Yudaev A.V. Value chain and supply chain management: differences and similarities. Management of economic systems: electronic scientific journal [Electronic resource]. URL: http://www.uecs.ru/index.php.

[7] Radaev, V.V. Who Owns Power in Consumer Markets: Relations of Retail Networks and Suppliers in Modern Russia. M.: Publ. House of the Higher School of Economics. 2011, 382.

[8] Alexsandr S. Kuznetsov. Russian Professor's meeting. Russian Journal of Physical Education and Sport. 2019, 14(1), pp. 17-22. DOI: 10.14526/2070-4798-2019-14-1-18-24

[9] Ajupov, A. Risk-management in economic and financial systems. International Business Management. 2016, 10(22), pp. 5227-5231 